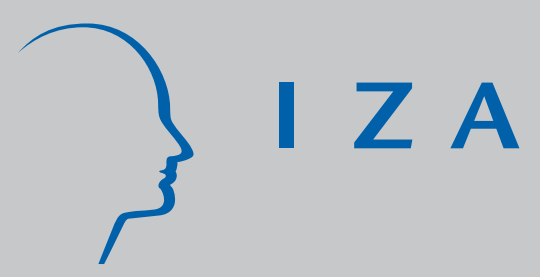

IZA DP No. 3597

New Estimates of the Effects of Minimum Wages in the U.S. Retail Trade Sector

J ohn T. Addison

McKinley L. Blackburn

Chad D. Cotti

July 2008 


\title{
New Estimates of the Effects of Minimum Wages in the U.S. Retail Trade Sector
}

\author{
John T. Addison \\ Queen's University Belfast, \\ University of South Carolina and IZA \\ McKinley L. Blackburn \\ University of South Carolina \\ Chad D. Cotti \\ University of Wisconsin Oshkosh
}
Discussion Paper No. 3597
July 2008

IZA

P.O. Box 7240

53072 Bonn

Germany

Phone: +49-228-3894-0
Fax: +49-228-3894-180
E-mail: iza@iza.org

Any opinions expressed here are those of the author(s) and not those of IZA. Research published in this series may include views on policy, but the institute itself takes no institutional policy positions.

The Institute for the Study of Labor (IZA) in Bonn is a local and virtual international research center and a place of communication between science, politics and business. IZA is an independent nonprofit organization supported by Deutsche Post World Net. The center is associated with the University of Bonn and offers a stimulating research environment through its international network, workshops and conferences, data service, project support, research visits and doctoral program. IZA engages in (i) original and internationally competitive research in all fields of labor economics, (ii) development of policy concepts, and (iii) dissemination of research results and concepts to the interested public.

IZA Discussion Papers often represent preliminary work and are circulated to encourage discussion. Citation of such a paper should account for its provisional character. A revised version may be available directly from the author. 
IZA Discussion Paper No. 3597

July 2008

\section{ABSTRACT \\ New Estimates of the Effects of Minimum Wages in the U.S. Retail Trade Sector}

This paper examines the impact of minimum wages on earnings and employment in selected branches of the retail-trade sector, 1990-2005, using county-level data on employment and a panel regression framework that allows for county-specific trends in sectoral outcomes. We focus on particular subsectors within retail trade that are identified as particularly low-wage. We find little evidence of disemployment effects once we allow for geographic-specific trends. Rather, in many sectors the evidence suggests modest (but robust) positive employment effects. One explanation we consider for these 'perverse' effects is that minimum wages may have significant influences on product demand shifts.

JEL Classification: J23, J38

Keywords: minimum wages, wages and employment, county-level data, spatial trends, border county analysis, unions, right-to-work states

Corresponding author:

John T. Addison

Queen's University Management School

Queen's University Belfast

Belfast BT7 1NN

Northern Ireland

United Kingdom

E-mail: j.addison@qub.ac.uk 
A common approach in the recent literature on the effect of minimum wages on employment has been to examine labor market outcomes in specific sectors of the economy that tend to pay workers at or close to the minimum. Studies using this approach initially focused on the fast-food restaurant sector, using data collected following or surrounding an increase in the minimum wage (for example, see Katz and Krueger, 1992; Card and Krueger; 1994; Card and Krueger, 2000; Neumark and Wascher, 2000). The general tenor of findings employing this approach offered little support for the presumption that higher minimum wages should lead to lower employment. ${ }^{1}$

Other specific low-wage sectors of the labor market have not received the same attention as the restaurant sector. One exception is the general retail sector where a limited number of studies have investigated potential disemployment effects (viz. Kim and Taylor, 1995; Partridge and Partridge, 1999; Sabia, 2006). Although the prevalence of minimum-wage workers in the general retail sector is considerably lower than in the case of restaurants, these studies have universally supported the notion that minimum wages lower employment.

The present paper adds to the research examining minimum wages in sectors other than restaurants by focusing on employment effects in specific subsectors of the retail trade sector. Our choice of particular subsectors hinges largely on their tendency to pay wages near the minimum wage. Using county-level data on employment reported by establishments in the period 1990-2005, we are able to examine how employment levels vary with the current minimum wage in that particular state. Our panel-data regression framework is similar to that of Neumark and Wascher (1992), allowing for both county and time fixed effects. One important enhancement to their framework, however, is our ability to allow for county-specific trends in

\footnotetext{
${ }^{1}$ More recent studies by Dube, Lester, and Reich (2007) and Addison, Blackburn, and Cotti (2008) that use a more comprehensive sample and extended time frame to examine minimum-wage effects in the restaurant sector also point to an absence of disemployment effects.
} 
sectoral outcomes, which specification materially impacts the estimate of the minimum wage effect.

Our results provide little support for the presence of disemployment effects in the retail trade sectors examined. In fact, many of our estimated elasticities actually suggest that increasing the minimum wage can modestly increase sectoral employment. Although such results may reflect various noncompetitive influences in the labor market, we incline to the view that they are instead more consistent with the possibility that advances in minimum wages stimulate sector-specific product demand.

\section{The Previous Literature on Minimum Wages in the Retail Sector}

In his case study of California's experience with raising its minimum wage in 1988, Card (1992) presented evidence that employment change in that state's retail trade sector developed in a manner similar to that of comparative states in which minima remained unchanged. Surprised by the apparent absence of disemployment effects, Kim and Taylor (1995) sought to re-examine employment outcomes in the retail trade sector in California in a more formal manner. Given the single change in the minimum wage for California, it was not possible to estimate minimumwage effects directly, so the authors instead attempted to estimate labor-demand functions for the various sectors making up the retail trade industry. This was accomplished primarily by looking at how employment changes within sectors of retail trade related to wage changes within those sectors. $^{2}$ Their primary data source is the County Business Patterns data from 1984 to 1989 . Kim and Taylor acknowledge that measurement error and the usual endogeneity problems in estimating demand functions will cause problems for ordinary least squares estimates, so they estimate their equations instrumenting for the change in wages using the lagged wage level and

\footnotetext{
${ }^{2}$ They also performed a very similar analysis using cross-county variation in the same variables, this time measured for all retail trade employment. The change variables were constructed as the change in California minus the change in the rest of the United States, thereby differencing out any industry-specific effects present in all states.
} 
average establishment size in the sector as instruments. Estimating their labor-demand functions separately for changes in adjacent years, both their OLS and instrumental variables results yield little support for a negative impact of wages on employment before the minimum wage change in 1988. However, regression estimates using 1988-89 changes (surrounding the 1988 minimum-wage increase) provide strong evidence of a downward-sloping demand curve, with an elasticity of roughly -1 . It is argued that the exogenous variation in wage changes created by the hike in the minimum wage explain the strong findings for the 1988-89 comparisons that are not replicated in the regressions for the individual years prior to the minimum-wage increase.

Card and Krueger (1995) criticize Kim and Taylor (1995) for the use of inadequate data and for an unsatisfactory choice of instruments. In their re-analysis, Card and Krueger also point out that the results are not robust to the use of a two-year difference (1987-89), even though the same minimum wage changes are relevant to those outcomes as they are to the 1988-89 difference. We, too, find Kim and Taylor’s choice of instruments unconvincing. In particular, in order to identify a demand equation one would normally use factors that shift wages strictly because of supply considerations. Yet, models - not least in the minimum wage literature often assume that demand responds to wages with a lag. Likewise, establishment size can be seen as a factor relevant to the determination of labor demand. Further, the lack of direct variation in minimum wages across sample observations in the setup of Kim and Taylor makes it difficult to argue convincingly that minimum wage changes led to the observed employment changes.

A combination of retail trade and nonprofessional industries was studied in the analysis by Orazem and Mattila (2002) of the Iowa minimum wage increases in the early 1990s. Part of their analysis examined how one-quarter (or four-quarter) employment changes in a specific sector and year responded to the ratio of the minimum wage to the (predicted) average wage for that sector and year. Their general finding was that employment growth was lower in sectors 
where the minimum wage ratio was higher (in a regression that examined a four-quarter difference in employment.) One peculiarity of their specification is that they use the employment growth rate as the dependent variable, whereas the typical specification in the literature uses the level (or log of the level) of employment. Orzarem and Mattila’s analysis is also weakened by the fact that all county/sectors experience the same time pattern for minimum wage changes. This renders their treatment similar to a state-level panel data analysis, but with no cross-state variation in the minimum wage. In these circumstances, they are able to estimate a minimum wage effect by using minimum wages divided by the county's average wage as their independent variable, so that average wage variation largely identifies the minimum wage effect. ${ }^{3}$ One weakness of their results is that there is little evidence that the minimum wage effect differs with the minimum-wage coverage rate in the sector. A separate analysis in their paper focuses on firm-level data, where covered and uncovered firms can be identified, but again the evidence suggests minimum wage effects that are just as large in uncovered firms as in covered firms.

Partridge and Partridge (1999) considered minimum-wage effects in retail trade using state-level data on employment taken from Employment and Earnings for 1984-89. As in Kim and Taylor (1995), the data set is constructed from an establishment-level survey on employment levels, which Partridge and Partridge use to estimate panel data models similar in construction to those of Neumark and Wascher (1992). Their results point to a negative influence of minimum wages on retail employment, although this negative impact only operates via a lagged effect of the minimum wage. Like Orazem and Mattila (2002), they estimate a regression in which the growth in employment is the dependent variable (although their minimum wage variable is not deflated by average wages). As their reported estimates have a positive coefficient on the contemporaneous minimum wage variable and a negative coefficient on the lagged minimum

\footnotetext{
${ }^{3}$ They also do not include time effects in their model, so some of the variation in the minimum wage variable also comes from changes over time in the minimum wage.
} 
wage, their findings are actually consistent with a positive minimum wage impact on employment if the typical specification is correct. ${ }^{4}$

Prompted as a response to a simple descriptive-statistics analysis of retail employment published by the Fiscal Policy Institute (2004), Sabia (2006) used data from the Outgoing Rotation Group sample of the Current Population Survey to consider whether minimum wages affected general retail trade employment over the $1979-2004$ period. ${ }^{5}$ He also uses the state-level panel data setup of Neumark and Wascher (1992), but with the dependent variable being the percentage of the adult population employed in retail trade. ${ }^{6}$ His results point to a negative impact of raising the minimum wage on retail trade employment, suggesting an elasticity of roughly -0.1 . The negative influences are even larger when focusing on the percentage of teenagers in retail trade, with an elasticity for this group in the range -0.3 to -0.4 . Similar elasticities are reported when the overall teenage employment-to-population ratio is used as the dependent variable. An analysis of work hours of teenagers in the retail trade sector points to minimum wages also reducing average work hours among those who stay employed. (However, no analysis of work hours for all workers in the retail sector is provided.) Although Sabia does use a first-order autocorrelation correction procedure in his estimation, the statistical support for his conclusions may be sensitive to his failure to allow for an unrestricted correlation structure for the error terms within a state (in this regard, see the comments of Bertrand, Duflo, and Mullainathan, 2004).

\footnotetext{
${ }^{4}$ If employment (E) is determined by the minimum wage (MW) in the (log) level equation $\mathrm{E}_{\mathrm{t}}=\beta_{0}+\beta_{1} \mathrm{MW}_{\mathrm{t}}+\mathrm{u}_{\mathrm{t}}$, the first-difference specification of Partridge and Partridge would be $\Delta \mathrm{E}_{\mathrm{t}}=\beta_{1} \mathrm{MW}_{\mathrm{t}}-\beta_{1} \mathrm{MW}_{\mathrm{t}-1}+\Delta \mathrm{u}_{\mathrm{t}}$. A positive coefficient on $\mathrm{MW}_{\mathrm{t}}$ and a negative coefficient on $\mathrm{MW}_{\mathrm{t}-1}$ could then be consistent with a positive minimum-wage effect.

${ }^{5}$ A substantial change in the industrial coding in the CPS occurred over this period. In particular, eating and drinking establishments are no longer included as part of the retail trade industry in the newer NAICS coding. Sabia uses consistent coding over time, although it is not clear whether he sought to be consistent with the newer coding or the older coding.

${ }^{6} \mathrm{He}$ also considers the percentage employed in small businesses, with qualitatively similar results to those for retail employment.
} 
In what follows, we also use the state-panel approach of Neumark and Wascher (1992) to examine potential minimum-wage effects on employment and earnings in retail trade. Our approach differs from that of Sabia (2006) in at least two important ways. First, we use more complete data on employment in retail trade by using county-level counts of employment from the Quarterly Census of Employment and Wages. In contrast, much of the previous research has used employment estimates from the Current Population Survey, which are often based on small samples when measured at the state level. Second, as sectors within retail trade vary substantially in the degree to which they can be characterized as 'low-wage,' at the outset we identify those particular retail sectors where employers are most likely to face higher costs as a result of minimum-wage increases. Furthermore, our analysis is based on a nationwide sample, rather than the limited geographic focus inherent in Kim and Taylor (1995) and Orazem and Mattila (2002). Finally, our empirical models can also be interpreted as reduced-form, thereby avoiding the inherent endogeneity problems faced in Kim and Taylor.

\section{Data}

\section{A. The QCEW}

The primary data source used in this study is the Quarterly Census of Employment and Wages (QCEW) from the Bureau of Labor Statistics (BLS). The QCEW reports quarterly county-level payroll data on private employment and earnings for narrowly defined industries. These data are collected from paperwork employers file in conjunction with the unemployment insurance program, which according to the BLS covers 99.7 percent of all wage and salary civilian employment. ${ }^{7}$ The industry definition of all firms in the data is coded according to the North American Industrial Coding System (NAICS), and aggregations of the data by county,

\footnotetext{
${ }^{7}$ http://www.bls.gov/cew/cewfaq.htm
} 
industry, and quarter are available to users, beginning with the initial data collection for the first quarter of 1990.

The data contained within the QCEW survey have many advantages over information found in other employment surveys. Principally, the QCEW provides census (rather than sample) observations of employment and earnings for detailed industrial specifications within a large number of narrowly defined geographic regions (in our case counties). Moreover, the data are available since 1990 and reported with a reasonably high frequency (that is, quarterly). The combination of all of these characteristics makes the QCEW a strong and flexible resource in the study of minimum wage effects. That said, it is not without imperfection. Notably, the survey does not distinguish between part-time and full time employees, and there is no measure of hours worked or the average wage. The sole earnings measure available is information on the average weekly earnings per worker in a specific industrial sector by county. ${ }^{8}$ Even so, the QCEW provides accurate and comprehensive measures of employment and earnings in highly disaggregated markets, and represents a data source that has been underutilized in research examining minimum-wage impacts on employment and earnings.

\section{B. Dependent Variables}

The dependent variables utilized in the present study are formed from an extract of quarterly observations of county-level employment and earnings for sub-sectors of the U.S. retail industry for the years 1990-2005. Specifically the sectors analyzed are Food and Beverage Stores (NAICS 445), Supermarkets (NAICS 44511), Convenience Stores (NAICS 44512), Specialty Food Stores (NAICS 4452), Beer, Wine, and Liquor Stores (NAICS 4453), Gasoline Stations (NAICS 447), Sporting Goods, Hobby, Book, and Music Stores (NAICS 451), General Merchandise Stores (NAICS 452), Department Stores (NAICS 4521), and Miscellaneous Store

\footnotetext{
${ }^{8}$ This measure includes most wage-like compensation, including tips, bonuses, stock options, and employer contributions to retirement plans.
} 
Retailers (NAICS 453). The method for selecting these sectors is provided in detail in the next section of the paper.

The BLS does censor sector-specific observations on employment and earnings if the number of establishments in the county is below a certain level in a particular quarter.

Specifically, the BLS withholds publication of data when necessary to protect the identity of cooperating employers, as there are industry/county combinations where the QCEW data would include a very small number of establishments. These data are duly suppressed in the QCEW public-use data for that industry/county, but may be included in the data at less detailed levels of aggregation (for example, in a more general definition of industry for that county). Hence, data on more disaggregated sectors will have much smaller sample sizes and be increasingly dominated by larger counties. Moreover, our samples were further reduced as we restricted our analysis to a balanced panel of counties, and so exclude any counties that failed to meet the censoring threshold in any of the quarters from 1990 to 2005.

The top two panels of Table 1 provide sector-specific summary statistics on the two dependent variables utilized in this analysis, while the final column of the table provides the number of counties available in each sector that meet the balanced panel restriction. ${ }^{9}$ One notable aspect of the employment averages presented in Table 1 is that average employment in certain highly disaggregated sectors (for example, supermarkets) actually exceeds the average employment in the more aggregated sector from which it is a part (for example, food and beverage stores). Although this would be impossible if the averages were drawn from the same sample, in this case it is simply because disaggregated samples are much more heavily censored; hence, averages are dominated by much larger counties.

\section{Independent Variables}

\footnotetext{
${ }^{9}$ Since the information in this column pertains to the number of counties that meet the balanced panel restriction of having data available throughout the 64 quarters, the number of quarterly observations utilized for each sector is simply the number of counties multiplied by 64 .
} 
The primary variable of interest is the enforced minimum wage in the relevant state, where the minimum wage variable is calculated as the higher of the state minimum wage (if one exists) and the federal minimum wage. Information on state minimum wages was collected from the material on state labor-law changes presented annually in the January edition of the Monthly Labor Review, along with previously published information on state minimum wages at the start of our sample period (see Addison and Blackburn, 1999). In the first quarter of 1990, there were fifteen states with minimum-wage levels above the federal mandate of \$3.35. Over the next 63 quarters there were 75 increases in state-level minimum wages in which the resulting minimum wage was above the federal standard. As well, there were four separate federal minimum wage increases over this period.

As we will discuss in detail in the followings section of the paper, we wish to supplement data on employment and earnings from the QCEW with additional measures that might reflect supply-and-demand factors in low-wage labor markets in a particular county. Specifically, the inclusion of additional controls is needed to capture the effects of other factors that may influence employment or earnings and vary across the sample through time. In attempting to measure county-specific, time-varying supply and demand factors that might influence employment and earnings, we collected data on total county employment and average weekly earnings for all industries combined from the QCEW. Data were also gathered on other measures that may be relevant to outcome indicators in low-wage labor markets; specifically, county-level population estimates (from the U.S. Census Bureau’s Population Estimates Program), county-level unemployment rates (from the Local Area Unemployment Survey), and state-level school enrollment (from the Current Population Survey).

The bottom panel of Table 1 provides summary statistics for all of the independent variables employed in our study. The averages provided were calculated from the sample of 
counties consistent with all analysis performed for the Food and Beverage Stores sector, the largest sample utilized in the primary component of the analysis.

\section{Theory and Empirical Specifications}

Our empirical models are based on a theoretical model of minimum wage effects (on employment) that allows for the possibility that minimum wages may not be effective or binding in a particular labor market. This possibility arises because the equilibrium wage may settle at a wage that is above the legislated wage floor. Assuming that demand evinces a constant elasticity-of-demand form, the relationship between observed employment (E) and the minimum wage $\left(\mathrm{w}_{\min }\right)$ would follow

$$
\log (\mathrm{E})=\mathrm{d} \eta \log \left(\mathrm{w}_{\min }\right)+\gamma^{\prime} \mathrm{x}
$$

where $\mathrm{x}$ includes other demand and supply factors that affect the employment outcome. The coefficient on the minimum wage is the product of the elasticity of labor demand $(\eta<0)$ and a dummy variable (d) equal to one if the minimum wage is above the competitive equilibrium wage. This formulation reflects the point that the minimum wage coefficient is either $\eta$ when the minimum wage is effective (as a minimum wage increase moves us along the demand curve) or zero when it is not (the minimum wage has no impact at the margin if it is not effective). ${ }^{10}$ Estimating this equation across a large sample should provide a coefficient roughly equal to $\eta$, where $\mathrm{p}$ is the percentage of markets where the minimum wage is effective. ${ }^{11}$

We also estimate earnings equations using our data, where in our theoretical framework the average earnings per week $(w)$ is given by

\footnotetext{
${ }^{10}$ This derivation is discussed in Addison, Blackburn, and Cotti (2008).

${ }^{11}$ In a regression framework, the expected value of the coefficient estimate would depend in practice on the percentage of the overall sample variation in minimum wages that is associated with counties where the minimum wage is effective; in particular, variation that is orthogonal to the other independent variables in the equation. If the variance of minimum wages is similar in counties where minimum wages are effective compared to those where minimum wages are not effective, the expected value of the coefficient would be $p \eta$.
} 


$$
\log (\mathrm{w})=\mathrm{d} \log \left(\mathrm{w}_{\min }\right)+\lambda^{\prime} \mathrm{x}
$$

The coefficient on the minimum wage variable reflects that the actual minimum wage effect is one if the minimum wage is effective, and zero if it is not effective. Estimation of this equation should provide a coefficient that can be interpreted as an estimate of the percentage of labor markets in which the minimum wage is effective. The ratio of the coefficient estimate on the log minimum wage in the employment equation to the estimate in the earnings equation should then provide a consistent estimate of the labor demand elasticity.

Our primary econometric model for estimating equations (1) and (2) can be written:

$$
\log \left(\mathrm{Y}_{\mathrm{ist}}\right)=\varphi \log \left(\mathrm{MW}_{\mathrm{st}}\right)+\gamma^{\prime} \mathrm{X}_{\mathrm{ist}}+\mu_{\mathrm{i}}+\lambda_{\mathrm{i}} \mathrm{t}+\tau_{\mathrm{t}}+\varepsilon_{\text {ist }}
$$

where i represents county, s state, and the quarter of the observation, and Y represents either employment or earnings. This specification allows for both fixed county effects and fixed quarter effects, as well as a time-trend in the error term that is county-specific. Given our estimation incorporates fixed effects, the vector X need include only factors that vary across counties and over time. Although the inclusion of fixed county and time effects is common in these type models, it is less common that a geographic-specific time trend is incorporated. Our concern is that, given the long time period from which our data are drawn, there may be a tendency for minimum wages to increase in counties as a result of an improvement in local-area employment conditions. Ignoring this tendency could lead to the spurious finding of positive employment effects.

A model incorporating geographic-specific trends has been termed a "random growth" model in the literature. When allowing for these trends, we estimate the model using a generalization of the fixed effects estimator that implicitly controls for the presence of these trends in the error term (see Wooldridge, 2002, pp. 317-322). The method involves sweeping out a county-specific linear trend in the independent variables, and using the detrended data to 
estimate the model. ${ }^{12}$ There remains the potential for the idiosyncratic error terms $(\varepsilon)$ to be correlated. Such correlation is a particular concern for error terms in the same state (given that the minimum wage is measured at the state level), so the standard errors for the coefficient estimates allow for an arbitrary pattern of correlation in the error terms across different observations from the same state. In estimating our models, we weight each observation by the average population size (across the 64 quarters) for that county. Population varies considerably across counties in the United States - at least partly because some states have more finelydefined county disaggregations than others - and we want counties that are a larger proportion of the overall labor market to be given more importance in estimating the coefficients.

The independent variables included in our equations are intended to capture influences on demand and/or supply in low-wage labor markets. As our dependent variable in the employment equations is total employment in a particular sector, we include two different controls for the size of the labor market (total employment across all industries, and population). The total average weekly earnings variable (across all sectors) controls for the equilibrium wage being high or low, which could have both demand and supply effects. Business-cycle effects are accounted for by the county-level unemployment rate, while the enrollment rate captures potential supply influences in low-wage labor markets. ${ }^{13}$

Disemployment effects from minimum wages are likely to be more evident in lower labor markets. Although the retail trade sector is well known to be a low-wage sector, the general sector is perhaps too broad - with too many workers earning more that the minimum wage - to

\footnotetext{
${ }^{12}$ The fixed-effects estimator sweeps out a county-specific constant, which leads to the use of demeaned data. In using detrended data, it is necessary that the standard errors be corrected for the additional parameters estimators, which, given the balanced nature of our panels, amounts roughly to multiplying the OLS standard errors with the detrended data by $\sqrt{64 / 62=1.016}$

${ }^{13}$ The inclusion of this variable in minimum-wage models has been controversial, as it is argued that the enrollment choice may itself be a function of the decision to work (see Card, Katz, and Krueger, 1994). However, this reverse causality effect is likely to be considerably less important when examining employment in more disaggregated sectors of the economy.
} 
anticipate strong effects from minimum wages. One advantage of the QCEW as a data source is that it is often possible to look at disaggregated subsectors of a main sector such as retail trade. As we have noted, the QCEW does not contain information on hourly wages. We therefore use data from the Outgoing Rotations Group sample of the Current Population Survey (CPS-ORG) from 2005 to identify particular sectors on which to focus our analysis.

The CPS-ORG provides sufficient information to identify the hourly wage of workers paid by the hour, along with the detailed industry codes for the worker based on the 2002 Census coding system. A crosswalk is provided which makes it easier to match up Census industry codes with NAICS codes (the coding system used in the QCEW), so we can usually link hourly wages by detailed industry in the CPS-ORG to sectors provided in the QCEW. To identify lowwage sectors that might be most affected by minimum wages, we calculated for each detailed industry the percentage of all workers who were paid by the hour and who had a wage that was (a) equal to or less than their minimum wage, (b) no more than $\$ 1$ above their minimum wage, or (c) no more than $\$ 2$ above their minimum wage. ${ }^{14}$ Table 2 provides a listing of every detailed industry with a percentage within $\$ 2$ of the minimum wage that was at least 20 percent.

When these percentages are calculated across all workers in the United States, we find that 2 percent are at or below the minimum, 5 percent at no more than $\$ 1$ above the minimum, and 9 percent no more than $\$ 2$ above the minimum. The general retail trade sector does exhibit a somewhat greater prevalence of low-wage workers, as the respective percentages in that sector are 2 percent, 8 percent, and 17 percent. And roughly one-half of the detailed industries that we identify in Table 2 are in the retail sector. Not surprisingly, the restaurant and other food services sector has some of the highest percentages of low-wage workers. But Table 2 also makes it clear that there are high concentrations of low-wage workers within particular subsectors of the retail trade industry as well.

\footnotetext{
${ }^{14}$ In these calculations, we used the prevailing minimum wage in the state of residence of the worker.
} 
Our particular choices of sectors for study attempts to balance concerns about a sufficient prevalence of low-wage workers with concerns that the QCEW also provide a sufficient number of counties for examination. The fact that both grocery stores and specialty food stores exhibit a high number of low-wage workers led us to examine the general food and beverage store sector (NAICS code 445), as well as its particular subsectors. Given the relatively large employment size in the grocery store sector, we decided to examine the separate supermarket and convenience store breakdown of that sector. Although the beer, wine, and liquor store sector did not meet the cutoffs for inclusion in Table 2, we nevertheless thought it would provide a useful comparison for the other subsectors of the food and beverage store sector.

Although the initial focus of our estimated models is upon food and beverage stores, we will subsequently address minimum wage effects in other parts of the retail trade sector that tend to have a high number of low-wage workers. Within the retail trade sector, gasoline stations actually have one of the highest percentages of workers within $\$ 2$ of the minimum wage. ${ }^{15}$ We group the sporting goods, hobby, book, and music stores together as one sector (NAICS 451) as each tends to display relatively high numbers of low-wage workers. This sector also makes for an interesting comparison with some of the others, as the demand for its products might be substantially affected if minimum wage increases primarily lead to an expansion in the discretionary budgets of teenagers. Both general merchandise and other store retailers show some evidence of a prevalence of low-wage workers, too, so we shall also examine them at a later stage in the paper.

There are a handful of other detailed industries outside the retail trade sector that meet our low-wage cutoff, but we chose not to examine these industries here. Cases in point are bowling centers, retail bakeries, video tape and disc rental, and car washes. These generally

\footnotetext{
${ }^{15}$ We calculate that only shoe stores have higher percentages, but the small size of the sector makes it impractical to study using QCEW data because of censoring.
} 
have such a small number of establishments per county that a good sized sample was not obtainable from the QCEW. Similarly, the private household service sector is not suitable for study with the QCEW given the likelihood of very small establishments (as households hire their own workers directly). For its part, cut and sew apparel manufacturing raises an interesting possibility for future study, although our sense is that modeling the mobility of firms across counties becomes important when examining industries in which the firm does not need to be located in the same county as its consumer base.

All of our estimates are calculated using a balanced panel of counties for that sector. This requires that there be a sufficient number of establishments in that county such that the number of establishments never falls below the censoring point for that sector. We chose to consider only the balanced panel, as we were concerned that the movements in and out of censored status could themselves be determined by the minimum wage: variation in the minimum wage could cause old establishments to close down or new ones to open. Again, the actual size of the sample will vary with the particular sector, as more finely-defined sectors will cause censoring to increase. ${ }^{16}$

\section{Empirical Results}

\section{A. Basic Results for the Food and Beverage Store Sector}

Our first set of estimated equations examine employment and earnings outcomes in the food and beverage store sector, along with the four subsectors that make up that sector. So as to demonstrate the importance of accounting for county-specific trends, we first present results using fixed-effects estimates that do not incorporate these trends. The fixed-effects results are

\footnotetext{
${ }^{16}$ As sample sizes do vary significantly depending on the level of disaggregation involved, there may be concerns that this difference in the counties included in the sample will lead to differences in estimation results between sectors, hence complicating inference. In order to test for this potential bias, we re-estimated the equations for larger-sample sectors using the same group of counties used in much smaller-sample sectors. The results were robust, indicating that differences in county samples do not drive differences in results observed across sectors.
} 
presented in Table 3. In our estimations, we weight by the average population size of the county and allow for correlation in the error terms in a given state in calculating the standard errors.

The prediction from competitive-market theory is that we should observe negative coefficient estimates for the minimum wage variable in employment equations and positive coefficients in earnings equations. As can be seen from the table, only two of the five sectors meet this expectation (convenience stores together with beer, wine, and liquor stores), and in each case one of the coefficient estimates is not statistically significant.

The general sense of the results in Table 3 is not supportive of the predictions of the competitive model. First, three of the minimum wage coefficient estimates in the employment equations are actually positive (although not statistically significant). Second, and more important, evidence of a positive earnings effect is expected, but the coefficient estimate is positive and statistically significant in only one case (beer, wine, and liquor stores). Indeed, the estimate is actually negative in two of the equations. It is difficult to see how increases in the minimum wages could not increase average earnings, especially in sectors where there is no evidence of disemployment effects. Although the results might be indicative of the irrelevance of minimum wages to this sector (and subsectors), they might also suggest that a simple fixedeffects specification inadequately captures the relationship between the minimum wage variable and county-specific components of the error term.

Estimates obtained from equations that allow for a county-specific trend in the error term are provided in Table 4, and show the importance of accounting for these trends. The nature of the estimated employment effects from minimum wage changes are quite similar across the five equations - all coefficient estimates are positive, and four are statistically significant. Note, too, that estimated effects are non-negligible: a 10 percent increase in the minimum wage is estimated to have a 1-2 percent increase in employment in these sectors. Of course, this is at odds with the conventional prediction of disemployment effects. But, as was observed earlier, much of the 
prior sector-specific research has failed to find evidence of disemployment effects, even if our finding of positive employment effects - in three out of four cases - is altogether more rare.

If minimum wages are effective in the food and beverage sector, then we should expect to find increasing effects on average earnings (see the lower panel of Table 4). For the sector as a whole, however, the estimated coefficient is only slightly positive, and is statistically insignificant. This result seems to be largely driven by the negative, but small and statistically insignificant coefficient estimate in the supermarket and other grocery store subsector that makes up the large majority of employment in the sector. Coefficient estimates in the other subsectors are all positive and statistically significant, and the larger coefficient estimates in convenience stores and specialty food stores compared to beer, wine and liquor stores are sensible given the greater prevalence of low-wage workers in those two sectors.

But the lack of evidence for a positive earnings effect in supermarkets is puzzling. We shall next offer one possible explanation for this seemingly anomalous supermarket sector result, but before doing so it is perhaps useful to consider possible explanations for the positive employment effects observed in Table 4. The modern literature on minimum wages has offered alternative theoretical predictions to those of the competitive model. Thus, both efficiency wage and monopsony models have been structured to allow for situations in which mandated wage increases would lead to employment increases, even if these arguments have not attracted a great degree of support. ${ }^{17}$ Although we can not completely dismiss such explanations, we think a more probable explanation may well reside in product demand shifts resulting from the increased earnings ceded low-wage workers by minimum wage increases.

\footnotetext{
${ }^{17}$ See the discussion in Chapter 11 of Card and Krueger (1995). The monopsony explanation has been criticized for the lack of evidence that increases in minimum wages lead to price reductions, as would be predicted by that model (see, for example, Aaronson, French, and MacDonald, 2008). Likewise, an efficiency wage explanation that involved employment increases would also predict price decreases. What evidence there is on prices is confined to the restaurant sector, and it is not clear whether the same result would be forthcoming in the retail trade sector.
} 
The pattern of employment effects in Table 4 is particularly intriguing in this regard. Overall product-demand effects from minimum wage increases might be modest given the small number of minimum-wage workers, but such product-demand effects as there are likely to be concentrated in sectors of the economy that make up a greater part of consumption for low-wage workers. Income effects in food purchases are likely to be large at the low end of the income distribution, and additional food purchases by low-wage workers are more likely in supermarkets and convenience stores than they are in specialty-food stores that cater more to high-income individuals. Finally, although the estimated employment effects in alcoholic beverage stores are smaller, it seems reasonable to surmise that the marginal propensity to consume alcoholic beverages among low-wage workers could be non-negligible.

\section{B. Right-to-Work Laws and the Supermarket Sector}

We earlier alluded to the absence of a positive earnings impact from minimum wages in the supermarket sector as puzzling. The presence of this puzzle may in turn cast doubt on our empirical approach for estimating minimum wage effects from the QCEW data. For example, supermarkets may respond to minimum wage increases not by decreasing employment but by decreasing hours per week for their workers, thereby causing both employment and weekly earnings to be unaffected by minimum wages. Unfortunately, the QCEW does not allow us to evaluate this explanation directly. On the other hand, it may be that minimum-wage workers are so unimportant in the supermarket sector that it is difficult to uncover the small positive effect on earnings given the precision of the estimates. We do not find this latter explanation convincing in general, given the large numbers of low-wage workers in the general grocery store sector reported in Table 2 (and the fact that the supermarket subsector makes up the large majority of employment in the grocery store sector in any given county). However, this explanation could hold in certain states, if institutional forces help to keep wages of hourly workers consistently above the minimum wage. 
An interesting characteristic of the grocery store sector is its high unionization rate. While the overall union coverage rate in retail trade is only 6 percent, within the grocery store sector it is 20 percent. ${ }^{18}$ The grocery store sector is again exceptional in this regard, as none of the other sectors that we consider has a unionization rate in excess of 8 percent. A strong union presence in a particular state should lead to higher average wages for workers in the grocery sector, as well as a less disperse distribution of wages that is likely to limit the number of workers being paid at (or close to) the minimum. In an attempt to address the importance of the union impact, we separated our sample into states with and without right-to-work laws. ${ }^{19}$ Our expectation is that the absence of a right-to-work law typically indicates a strong union environment in a state that should show up both in higher union percentages and a greater concern about potential unionization among grocery store employers. ${ }^{20}$ Our expectation, then, is that the evidence for the usual effects of minimum wages should be concentrated in the right-towork states.

Estimated regressions with county-specific trends are reported separately for right-towork and non-right-to-work states in Table 5. We report estimates for the general food and beverage store sector, as well as for the two subsectors that make up grocery stores. As is apparent, we now find statistically significant evidence of a disemployment effect in supermarkets, albeit restricted to states with right-to-work laws. This result is mirrored in the

\footnotetext{
${ }^{18}$ These values are for 2005, and are taken from the Union Membership and Coverage Database of Barry Hirsch and David Macpherson (available at http://unionstats.com). Separate figures are not available for the supermarket and convenience store sectors, although our expectation is that union coverage is considerably higher in the supermarket wing of the grocery store sector.

${ }^{19}$ According to the CPS-ORG, during our sample period union coverage in the grocery store sector in right-to-work states is 7 percent, while in non-right-to-work states union coverage is 29 percent. Moreover, the average hourly wage in the grocery store sector in right-to-work states (\$8.58 in 2005 dollars) is lower than that in non-right-towork states (\$9.89). Also, the average difference between a worker's hourly wage and the relevant minimum wage is higher by more than a dollar in non-right-to-work states, demonstrating that minimum wages are much more likely to be effective in right-to-work states.

${ }^{20}$ Whether right-to-work laws directly inhibit unionization attempts, or simply reflect a general negative attitude towards the union movement in that state, has been debated in the literature (see, for example, Moore, 1998). This debate is not important to our use of right-to-work status as an indicator of the general health of the union movement.
} 
general food and beverage store sector results. The results also suggest a positive earnings effect in supermarkets, again consistent with a high proportion of workers in that sector being directly affected by the minimum wage increase. In non-right-to-work states, we do not find statistically significant evidence for either employment or earnings - consistent with minimum wages not being generally effective in those states.

The results for the convenience store subsector are considerably more similar between the two types of states, perhaps reflecting a low union threat in that sector, even in non-right-to-work states. Positive earnings effects are found for both types of states, and the positive employment effect (statistically significant only in non-right-to-work states) may indicate a demand effect from the increase in the income of minimum wage workers.

\section{Regression Estimates Using Border Counties}

Our analysis controls for influences on retail trade employment that may evolve over time by incorporating county-specific trends in our model. A recent paper by Dube, Lester, and Reich (2007) suggests an alternative approach for controlling for trends that does not involve a functional form assumption about that trend. Rather, they assume a common trend for counties that border each other but are in different states, and then allow this trend to follow any possible pattern over time. The fact that minimum wages will often differ between border counties allows for identification of a minimum wage effect. As a consideration of the robustness of our findings to the method for handling trend effects, we applied this border-county approach to our data from the food and beverage sector.

Estimation of the regression model allowing border-county effects would be straightforward if each border county in a given state bordered only one county from the border state. In practice, this is not the usual case, so that any given border county will share a border with up to eight counties in the other state. We follow the approach of Dube, Lester, and Reich (2007) by including a given county in the regression analysis multiple times, once for each 
county it borders. For example, suppose a given county has two border counties. The 64 observations (over time) for that county will be included in the sample the first time, with a fixed effect that is shared with one of the border counties. This fixed effect is allowed to be different in each quarter, which in essence serves to difference all the variables between the two counties. Then, the same 64 observations for that county will be included a second time, this time with a fixed effect shared with the other border county. The observations for a given county are weighted by the inverse of the number of border counties for that county in the sample, to attempt to account for the repeated entries of the observation for a given county.

There are some obvious problems with this approach. In our example, the observed employment in a county is modeled once with a dummy variable effect shared with one border county. Then, that same observation is modeled omitting this effect but now including another effect shared with another border county (an effect not included when that observation was modeled the first time). However, our intention here, however, is not to develop a method of analysis capable of exploiting border-county similarities in a more consistent fashion, but rather to see whether or not an alternative approach that has been suggested in the literature for handling trend effects reaches conclusions different from those using our detrended analysis.

Regression estimates for the food and beverage sector using the Dube, Lester, and Reich approach are reported in Table 6. The general pattern of results is not dissimilar to those using the detrended data (Table 4), although there are some differences in the magnitude of the effects. Using the national sample, there is little indication of any disemployment effects, with some of the sectors providing large positive employment effects. Indeed, the estimated employment elasticities of roughly 0.5 in the convenience store and alcoholic-beverage store subsectors are difficult to believe. On the other hand, the magnitude of the estimated effects on average earnings is quite similar in Tables 4 and 6, especially for convenience, specialty food, and alcoholic-beverage stores. The estimates from the border-county analysis are not statistically 
significant in two of those sectors, however, due to a higher imprecision in the border-county estimates.

\section{Minimum Wage Effects in Other Retail Trade Sectors}

As noted in the discussion of Table 2, there are several other sectors of the retail trade industry with a relatively high frequency of low-wage workers. As before, we are limited in examining some of the more detailed sectors (such as shoe stores) by the county-level censoring in the QCEW. In Table 7, we present results - reverting back to our detrended data approach for some of the more frequently available subsectors that also tend to have a high prevalence of low-wage workers.

Given its typically small establishment size and high product demand, the gasoline station sector offers a natural focus. It has also one of the highest percentages of workers earning within $\$ 2$ of the minimum wage in the entire retail trade. Our minimum-wage coefficient estimate in the employment equation for this sector is positive but statistically insignificant, while the minimum-wage effect on average earnings in the sector appears to be positive. This pattern of results is as we would expect were minimum wages to have essentially no effect on employment and so increase the earnings of workers in that sector. The positive employment effect from minimum wages suggested for the sporting goods, hobby, book, and music stores agglomeration is consistent with a stronger product demand effect in that sector, which might be expected given the large number of teenagers among minimum-wage workers. Again, the estimated effects are consistent with a positive average earnings effect in that sector - one that appears to be smaller than among gasoline stations, as might be expected given the somewhat high prevalence of low-wage workers in the latter branch.

Table 7 also presents estimates for the general merchandise store sector, as well as for the department store subsector. The general merchandise sector is actually made up of two primary subsectors: department stores; and miscellaneous general merchandise. While Table 2 only 
identifies the latter subsector as low-wage, the department-store sector only narrowly misses the cutoff (19 percent of workers are at a wage no more than $\$ 2$ above the minimum). For general merchandise, and for department stores, we find the expected positive earnings impact. We find it somewhat surprising, however, that there are such strong suggested positive employment effects indicated in these regressions, especially the large estimated effect for department stores. Department stores are increasingly made up of discount stores (such as Wal-Mart) over this period, so some positive employment effect is perhaps not surprising.

As a final sector of the retail trade industry, we examined establishments classified as part of miscellaneous store retailers. This hodgepodge includes florists, office supplies, gift and novelty shops, used merchandise, pet supplies, art dealers, and even manufactured home dealers. Given this composition, strong product demand effects are not likely, and our estimates do not suggest that minimum wages increase employment in this sector. There was some indication in Table 2 that at least some of the subsectors within this sector had a high prevalence of low-wage workers - particularly workers in used merchandise stores, where 7 percent of workers were paid at the minimum wage in 2005 - so the evidence of an increasing impact on earnings in this sector is not unexpected. ${ }^{21}$

\section{Summary and Discussion}

We have used county-level employment statistics in low-wage retail-trade sectors to examine whether or not employment in these sectors responds to changes in the minimum wage relevant to that county. Our estimated regression models do not suggest that increasing the minimum wage tends to reduce employment levels in the sectors we examine, and in many cases we find evidence pointing to increased employment from increasing the minimum wage. A

\footnotetext{
${ }^{21}$ A separate analysis of the used merchandise sector was not feasible, however, given the typically small number of such establishments in most counties.
} 
crucial component of our empirical models is the inclusion of county-level trends in our regressions, a specification generalization often ignored in previous research. In our results, there is some suggestion that the minimum wage effect may vary across location - for example, a finding of no employment effect from the minimum wage in the grocery store sector in general masks the fact that there appears to be a small reducing impact of the minimum wage in right-towork law states. That said, the general impact of the minimum wage in the retail trade sectors is not consistent with the reductions in employment suggested in prior research for the retail trade sector as a whole.

The census-type QCEW data we analyze is arguably preferable to the sample-based individual-level or establishment-level data deployed in much prior research on the retail trade sector. Nevertheless, it is not without blemish: although the QCEW does provide information on number of employees, it does not provide any indication of the work hours of those employees. One of the possible explanations for our findings of positive employment effects in some retail trade sectors is that increases in the minimum wage cause firms to reduce work hours per worker. We doubt this explanation, for two reasons. First, Zavodny (1999) has carefully examined the impact of minimum wages on the work hours of teenagers, failing to find reliable evidence that minimum wages reduce hours. Second, our own estimates suggest that minimum wages tend to increase the weekly earnings of workers in most sectors, with estimated effects that are of similar magnitude to the percentages that might be directly affected by minimum wages in those sectors. If minimum wages were leading to reductions in work hours, we would anticipate that the minimum wage impact on weekly earnings per worker would be small (or even negative). ${ }^{22}$

\footnotetext{
${ }^{22}$ The one exception is the lack of evidence of any effect from minimum wage increases on weekly earnings in grocery stores in non-right-to-work law states. Although this finding might reflect a decrease in work hours for workers in those states, we think the more likely explanation is that the minimum wage is so unlikely to be effective in those states that any increasing impact on earnings is necessarily difficult to isolate in our data.
} 
An alternative explanation for the pattern of findings across different retail trade sectors is that minimum wages also have effects on product demand. We find evidence consistent with such an impact from sectors such as convenience stores, alcoholic-beverage stores, and hobbytype stores - all of which tend to have estimated minimum-wage employment effects that are positive, even though in most cases the prevalence of low-wage workers in these sectors is not particularly high. If minimum-wage increases do tend to increase the purchasing power of lowwage workers, then this pattern of product-demand shifts would seem likely. We readily concede that our evidence is at best suggestive in this regard, and that a more complete evaluation of this explanation requires additional data on actual sales in these sectors. Economists researching minimum-wage impacts have tended to neglect possible productdemand effects, perhaps on the basis of a theoretical presumption that these would have to be small. ${ }^{23}$ Albeit not conclusive, the evidence supplied here suggests that this dismissal may be unwarranted.

\footnotetext{
${ }^{23}$ This expectation might be based on the presumption that minimum wage increases are passed on fully as price increases in the long-run, which should dampen any product-demand effects. However, to the extent that minimum wages actually represent transfers from firms to workers, rather than from consumers to workers, increased product demand could still occur. The fact that minimum-wage workers (such as teenagers) may have a higher marginal propensity to consume than consumers in general could also affect whether product demand effects are likely relevant.
} 


\section{References}

Aaronson, Daniel, Eric French, and James MacDonald. 2005. “The Minimum Wage, Restaurant Prices, and Labor Market Structure.” Unpublished paper, Federal Reserve Bank of Chicago.

Addison, John T. and McKinley L. Blackburn. 1999. "Minimum Wages and Poverty.” Industrial and Labor Relations Review, 52(3): 393-409.

Addison, John T., McKinley L. Blackburn, and Chad D. Cotti. 2008. “County-Level Estimates of the Effects of Minimum Wages on Labor Market Outcomes.” IZA Discussion Paper No. 3300. Bonn: Institute for the Study of Labor.

Bertrand, Marianne, Ester Duflo, and Sendhil Mullainathan. 2004. “How Much Should We Trust Differences-in-Differences Estimates?” Quarterly Journal of Economics, 119(1): 249-275.

Card, David. 1992. "Do Minimum Wages Reduce Employment? A Case Study of California, 1987-1989.” Industrial and Labor Relations Review, 46(1): 38-54.

Card, David, Lawrence F. Katz, and Alan B. Krueger. 1994. “Comment on David Neumark and William Wascher: 'Employment Effects of Minimum and Subminimum Wages: Panel Data on State Minimum Wage Laws.” Industrial and Labor Relations Review, 47(3): 487-496.

Card, David and Alan B. Krueger. 1994. "Minimum Wages and Employment: A Case study of the Fast-Food Industry in New Jersey and Pennsylvania.” American Economic Review, 84(5): 772-793.

Card, David and Alan B. Krueger. 1995. Myth and Measurement: The New Economics of the Minimum Wage. Princeton, NJ: Princeton University Press.

Card, David and Alan B. Krueger. 2000. "Minimum Wages and Employment: A Case Study of the Fast-Food Industry in New Jersey and Pennsylvania: Reply.” American Economic Review, 90(5): 1397-1420.

Deere, Donald, Kevin Murphy, and Finis Welch. 1995. “Employment and the 1990-1991 Minimum Wage Hike.” American Economic Review, 85(2): 232-237.

Dube, Andrajit, T., William Lester, and Michael Reich. 2007. "Minimum Wage Effects Across State Borders: Estimates Using Contiguous Counties.” Working Paper, Institute for Research on Labor and Employment, University of California, Berkeley.

Fiscal Policy Institute. 2004. "State Minimum Wages and Employment in Small Businesses.” http://www.fiscalpolicy.org/minimumwageandsmallbusiness.pdf

Katz, Lawrence F. and Alan B. Krueger. 1992. "The Effect of the Minimum Wage on the Fast Food Industry.” Industrial and Labor Relations Review, 46(1): 6-21.

Kim, Taeil and Lowell J. Taylor. 1995. “The Employment Effect in Retail Trade of California’s 1988 Minimum Wage Increase.” Journal of Business and Economic Statistics. 13(2): 175-182. 
Moore, William J. 1998. “The Determinants and Effects of Right-to-Work Laws: A Review of the Recent Literature.” Journal of Labor Research, 19(3): 445-469.

Neumark, David and William Wascher. 1992. "Employment Effects of Minimum and Subminimum Wages: Panel Data on State Minimum Wage Laws.” Industrial and Labor Relations Review, 46(1): 55-81.

Neumark, David and William Wascher. 2000. “The Effect of New Jersey’s Minimum Wage Increase on Fast-Food Employment: A Reevaluation Using Payroll Records.” American Economic Review, 90(5): 1362-1396.

Neumark, David and William Wascher. 2006. "Minimum Wages and Employment: A Review of Evidence from the New Minimum Wage Research.” NBER Working Paper No. 12663.

Cambridge, MA: National Bureau of Economic Research.

Neumark, David and William Wascher. 2007. "Minimum Wages, the Earned Income Tax Credit and Employment: Evidence from the Post-Welfare Reform Era.” NBER Working Paper No. 12915. Cambridge, MA: National Bureau of Economic Research.

Partridge, Mark D. and Jamie S. Partridge. 1999. "Do Minimum Wage Hikes Reduce Employment? State-Level Evidence from the Low-Wage Retail Sector." Journal of Labor Research. 20(3): 393-413.

Orazem, Peter and F., and J. Peter Mattila. 2002. "Minimum Wage Effects on Hours, Employment, and Number of Firms: The Iowa Case.” Journal of Labor Research, 23(4): 3-23

Sabia, Joseph J. 2006. “The Effect of Minimum Wage Increases on Retail and Small Business Employment.” Employment Policies Institute Working Paper, Washington, D.C.

Wooldridge, Jeffrey M. 2002. Econometric Analysis of Cross Section and Panel Data. Cambridge, MA: MIT Press.

Zavodny, Madeline. 2000. “The Effect of the Minimum Wage on Employment and Hours.” Labour Economics. 7(4): 729-750. 


\begin{tabular}{|c|c|c|c|}
\hline \multirow[t]{3}{*}{ Descriptive Statist } & or the Co & ample: 199 & \\
\hline & \multicolumn{3}{|c|}{ County Level Means } \\
\hline & Mean & Std. Dev. & $\begin{array}{l}\text { Number of Counties } \\
\text { (balanced sample) }\end{array}$ \\
\hline \multicolumn{4}{|l|}{ Total Employment in Sector } \\
\hline$\overline{\text { Food and Beverage Stores }}$ & 1,267 & 3,344 & 2,158 \\
\hline Grocery Stores & 1,691 & 3,538 & 1,269 \\
\hline Supermarkets and Other Grocery Stores & 2,628 & 4,481 & 620 \\
\hline Convenience Stores & 276 & 389 & 412 \\
\hline Specialty Food Stores & 746 & 837 & 403 \\
\hline Beer, Wine, and Liquor Stores & 262 & 371 & 398 \\
\hline Gasoline Stations & 360 & 644 & 2,371 \\
\hline Sporting Goods, Hobby, Book, and Music Stores & 659 & 1,339 & 877 \\
\hline General Merchandise Stores & 2,119 & 3,864 & 1,132 \\
\hline Department Stores & 3,303 & 4,275 & 361 \\
\hline Miscellaneous Store Retailers & 536 & 1,345 & 1,565 \\
\hline \multicolumn{4}{|l|}{ Average Weekly Earnings } \\
\hline Food and Beverage Stores & 311 & 77 & 2,158 \\
\hline Grocery Stores & 323 & 80 & 1,269 \\
\hline Supermarkets and Other Grocery Stores & 348 & 91 & 620 \\
\hline Convenience Stores & 266 & 72 & 412 \\
\hline Specialty Food Stores & 405 & 136 & 403 \\
\hline Beer, Wine, and Liquor Stores & 369 & 149 & 398 \\
\hline Gasoline Stations & 278 & 64 & 2,371 \\
\hline Sporting Goods, Hobby, Book, and Music Stores & 290 & 81 & 877 \\
\hline General Merchandise Stores & 311 & 62 & 1,132 \\
\hline Department Stores & 326 & 60 & 361 \\
\hline Miscellaneous Store Retailers & 334 & 105 & 1,565 \\
\hline \multicolumn{4}{|l|}{ Other Variables } \\
\hline Total Private Employment & 44,824 & 140,296 & 2,158 \\
\hline Total Private Average Weekly Earnings & 533 & 132 & 2,158 \\
\hline Population (annual) & 122,086 & 339,023 & 2,158 \\
\hline Unemployment Rate (all industries) & 5.93 & 2.67 & 2,158 \\
\hline Real Minimum Wage & 5.65 & 0.42 & 2,158 \\
\hline Enrollment Rate (State-level) & 0.46 & 0.11 & 2,158 \\
\hline
\end{tabular}




\begin{tabular}{|c|c|c|c|c|}
\hline Table 2 & \multicolumn{4}{|c|}{$\begin{array}{l}\text { Industries with at least } 20 \text { Percent of Workers Earning No More than } \\
\text { \$2 Above the Minimum Wage in } 2005\end{array}$} \\
\hline Industry (NAICS Code) & $\begin{array}{l}\text { Percentage of } \\
\text { Work Force }\end{array}$ & $\begin{array}{l}\text { Percentage at or } \\
\text { below the } \\
\text { Minimum Wage }\end{array}$ & $\begin{array}{l}\text { Percentage } \\
\text { below the } \\
\text { Minimum } \\
\text { Wage plus \$1 } \\
\end{array}$ & $\begin{array}{l}\text { Percentage } \\
\text { below the } \\
\text { Minimum } \\
\text { Wage plus \$2 }\end{array}$ \\
\hline \multicolumn{5}{|l|}{ Manufacturing } \\
\hline Retail bakeries (311811) & $0.1 \%$ & $6.0 \%$ & $14.6 \%$ & $27.6 \%$ \\
\hline Cut and sew apparel (3152) & 0.2 & 7.1 & 15.1 & 21.9 \\
\hline \multicolumn{5}{|l|}{ Retail Trade } \\
\hline Grocery stores (4451) & 2.2 & 3.0 & 12.6 & 26.9 \\
\hline Specialty food stores (4452) & 0.2 & 5.1 & 14.7 & 23.5 \\
\hline Gasoline stations (447) & 0.4 & 2.9 & 13.4 & 30.9 \\
\hline $\begin{array}{l}\text { Clothing and accessories, } \\
\text { except shoes (most of 448) }\end{array}$ & 0.6 & 4.3 & 11.8 & 23.9 \\
\hline Shoe stores (44821) & 0.1 & 2.6 & 14.7 & 31.8 \\
\hline $\begin{array}{l}\text { Sporting goods, camera, and } \\
\text { hobby stores } \\
(44313,45111,45112)\end{array}$ & 0.3 & 1.5 & 10.1 & 23.6 \\
\hline $\begin{array}{l}\text { Sewing, needlework, and } \\
\text { piece goods stores (45113) }\end{array}$ & 0.04 & 1.4 & 12.2 & 23.0 \\
\hline Music stores $(45114,45122)$ & 0.1 & 3.5 & 15.7 & 26.7 \\
\hline $\begin{array}{l}\text { Book stores and news dealers } \\
\text { (45121) }\end{array}$ & 0.1 & 4.6 & 13.2 & 22.9 \\
\hline $\begin{array}{l}\text { Misc. general merchandise } \\
\text { (4529) }\end{array}$ & 0.4 & 4.4 & 17.7 & 27.8 \\
\hline Used merchandise (4533) & 0.1 & 6.9 & 16.4 & 28.5 \\
\hline $\begin{array}{l}\text { Gift, novelty, and souvenir } \\
\text { shops (45322) }\end{array}$ & 0.2 & 3.1 & 13.7 & 29.0 \\
\hline \multicolumn{5}{|l|}{ Information } \\
\hline $\begin{array}{l}\text { Motion picture and video } \\
\text { industries (5121) }\end{array}$ & 0.2 & 2.9 & 13.8 & 22.7 \\
\hline \multicolumn{5}{|c|}{ Real Estate and Rental and Leasing } \\
\hline $\begin{array}{l}\text { Video tape and disc rental } \\
\text { (53223) }\end{array}$ & 0.1 & 6.2 & 28.9 & 45.5 \\
\hline \multicolumn{5}{|c|}{ Arts, Entertainment, Recreation, Accommodation, and Food Services } \\
\hline Bowling Centers (71395) & 0.04 & 6.4 & 17.4 & 28.0 \\
\hline $\begin{array}{l}\text { Other amusement, gambling } \\
\text { and recreation (most of 713) }\end{array}$ & 1.2 & 4.0 & 11.9 & 21.3 \\
\hline $\begin{array}{l}\text { Restaurants and other Food } \\
\text { Services (most of 722) }\end{array}$ & 6.0 & 14.4 & 29.0 & 42.0 \\
\hline $\begin{array}{l}\text { Drinking places, alcoholic } \\
\text { beverages (7224) }\end{array}$ & 0.2 & 9.7 & 17.5 & 26.1 \\
\hline \multicolumn{5}{|l|}{ Other Services } \\
\hline Car washes (811192) & 0.1 & 7.5 & 20.8 & 35.5 \\
\hline Private household (814) & 0.7 & 6.3 & 13.2 & 23.9 \\
\hline \multicolumn{5}{|c|}{$\begin{array}{l}\text { Source: } 2005 \text { CPS-ORG } \\
\text { Note: Excludes workers in the agriculture, forestry, and fishing industries. The prevailing minimum wage } \\
\text { in the worker's state is used in constructing the percentages. The statistics represent the percentage of } \\
\text { workers that are both paid by the hour and have a wage in the stated range. These percentages are taken } \\
\text { across all workers, both hourly and salaried. }\end{array}$} \\
\hline
\end{tabular}




\begin{tabular}{|c|c|c|c|c|c|}
\hline Table 3 & \multicolumn{5}{|c|}{ Fixed Effects Regression Estimates for the Food and Beverage Store Sector } \\
\hline Industry & $\begin{array}{c}\text { Food and Beverage } \\
\text { Stores }\end{array}$ & $\begin{array}{c}\text { Supermarkets and } \\
\text { Other Grocery } \\
\text { Stores }\end{array}$ & $\begin{array}{c}\text { Convenience } \\
\text { Stores }\end{array}$ & $\begin{array}{l}\text { Specialty Food } \\
\text { Stores }\end{array}$ & $\begin{array}{l}\text { Beer, Wine, and } \\
\text { Liquor Stores }\end{array}$ \\
\hline NAICS Code & 445 & 44511 & 44512 & 4452 & 4453 \\
\hline Dep. Variable & \multicolumn{5}{|c|}{ (a) Employment } \\
\hline Minimum Wage & $\begin{array}{c}0.170 \\
(0.134)\end{array}$ & $\begin{array}{c}0.128 \\
(0.167)\end{array}$ & $\begin{array}{l}-0.314 * \\
(0.177)\end{array}$ & $\begin{array}{c}0.197 \\
(0.201)\end{array}$ & $\begin{array}{l}-0.183 \\
(0.194)\end{array}$ \\
\hline Population & $\begin{array}{c}0.334^{* *} \\
(0.113)\end{array}$ & $\begin{array}{c}0.151 \\
(0.265)\end{array}$ & $\begin{array}{c}0.911^{* *} \\
(0.359)\end{array}$ & $\begin{array}{c}0.238 \\
(0.199)\end{array}$ & $\begin{array}{l}-0.246 \\
(0.176)\end{array}$ \\
\hline Total Employment & $\begin{array}{c}0.400 * * \\
(0.055)\end{array}$ & $\begin{array}{c}0.418^{* *} \\
(0.146)\end{array}$ & $\begin{array}{c}0.234 \\
(0.257)\end{array}$ & $\begin{array}{l}0.672 * * \\
(0.132)\end{array}$ & $\begin{array}{c}0.683^{* *} \\
(0.130)\end{array}$ \\
\hline Total Average Weekly & $0.064^{*}$ & 0.052 & -0.141 & -0.090 & 0.014 \\
\hline Earnings & $(0.037)$ & $(0.059)$ & $(0.136)$ & $(0.096)$ & $(0.096)$ \\
\hline Unemployment Rate & $\begin{array}{c}-0.001 \\
(0.004)\end{array}$ & $\begin{array}{l}-0.003 \\
(0.006)\end{array}$ & $\begin{array}{c}-0.010 \\
(0.013)\end{array}$ & $\begin{array}{c}0.003 \\
(0.009)\end{array}$ & $\begin{array}{c}0.012 \\
(0.008)\end{array}$ \\
\hline Enrollment Rate & $\begin{array}{c}-0.020 \\
(0.550)\end{array}$ & $\begin{array}{l}-0.004 \\
(0.095)\end{array}$ & $\begin{array}{c}-0.289 * * \\
(0.135)\end{array}$ & $\begin{array}{c}-0.170^{* *} \\
(0.077)\end{array}$ & $\begin{array}{c}-0.103 \\
(0.097)\end{array}$ \\
\hline Dep. Variable & \multicolumn{5}{|c|}{ (b) Earnings } \\
\hline Minimum Wage & $\begin{array}{c}-0.077 \\
(0.094)\end{array}$ & $\begin{array}{l}-0.130 \\
(0.110)\end{array}$ & $\begin{array}{c}0.039 \\
(0.074)\end{array}$ & $\begin{array}{c}0.045 \\
(0.160)\end{array}$ & $\begin{array}{c}0.168^{* *} \\
(0.076)\end{array}$ \\
\hline Population & $\begin{array}{l}0.104 * * \\
(0.044)\end{array}$ & $\begin{array}{c}0.089 \\
(0.074)\end{array}$ & $\begin{array}{c}-0.098 \\
(0.120)\end{array}$ & $\begin{array}{c}-0.262^{* *} \\
(0.111)\end{array}$ & $\begin{array}{c}0.156 \\
(0.186)\end{array}$ \\
\hline Total Employment & $\begin{array}{c}0.038 \\
(0.027)\end{array}$ & $\begin{array}{c}0.068 \\
(0.056)\end{array}$ & $\begin{array}{c}0.147 \\
(0.094)\end{array}$ & $\begin{array}{l}0.235 * * \\
(0.073)\end{array}$ & $\begin{array}{c}0.094 \\
(0.074)\end{array}$ \\
\hline Total Average Weekly & $0.082 * *$ & 0.037 & $0.126^{* *}$ & 0.074 & 0.175 \\
\hline Earnings & $(0.025)$ & $(0.038)$ & $(0.064)$ & $(0.070)$ & $(0.071)$ \\
\hline Unemployment Rate & $\begin{array}{c}0.007 * * \\
(0.002)\end{array}$ & $\begin{array}{c}0.011^{* *} \\
(0.003)\end{array}$ & $\begin{array}{c}0.001 \\
(0.003)\end{array}$ & $\begin{array}{l}-0.004 \\
(0.005)\end{array}$ & $\begin{array}{c}0.011^{* *} \\
(0.004)\end{array}$ \\
\hline Enrollment Rate & $\begin{array}{c}-0.022 \\
(0.026)\end{array}$ & $\begin{array}{l}-0.040 \\
(0.039)\end{array}$ & $\begin{array}{c}-0.148 * * \\
(0.064)\end{array}$ & $\begin{array}{c}0.040 \\
(0.062)\end{array}$ & $\begin{array}{c}0.036 \\
(0.068)\end{array}$ \\
\hline
\end{tabular}




\begin{tabular}{|c|c|c|c|c|c|}
\hline Table 4 & \multicolumn{5}{|c|}{ Regression Estimates with County-Level Trends: Food and Beverage Store Sector } \\
\hline Industry & $\begin{array}{c}\text { Food and Beverage } \\
\text { Stores }\end{array}$ & $\begin{array}{c}\text { Supermarkets and } \\
\text { Other Grocery Stores }\end{array}$ & $\begin{array}{l}\text { Convenience } \\
\text { Stores }\end{array}$ & $\begin{array}{l}\text { Specialty Food } \\
\text { Stores }\end{array}$ & $\begin{array}{c}\text { Beer, Wine, and } \\
\text { Liquor Stores }\end{array}$ \\
\hline NAICS Code & 445 & 44511 & 44512 & 4452 & 4453 \\
\hline Dep. Variable & \multicolumn{5}{|c|}{ (a) Employment } \\
\hline Minimum Wage & $\begin{array}{l}0.225^{* *} \\
(0.114)\end{array}$ & $\begin{array}{l}0.210^{*} \\
(0.128)\end{array}$ & $\begin{array}{c}0.227 * * \\
(0.116)\end{array}$ & $\begin{array}{c}0.067 \\
(0.110)\end{array}$ & $\begin{array}{l}0.101^{* *} \\
(0.048)\end{array}$ \\
\hline Population & $\begin{array}{l}0.414^{* *} \\
(0.154)\end{array}$ & $\begin{array}{l}0.526 * * \\
(0.231)\end{array}$ & $\begin{array}{c}0.821 \\
(0.581)\end{array}$ & $\begin{array}{l}-0.693 \\
(0.521)\end{array}$ & $\begin{array}{l}-0.035 \\
(0.273)\end{array}$ \\
\hline Total Employment & $\begin{array}{c}0.468^{* *} \\
(0.053)\end{array}$ & $\begin{array}{l}0.520 * * \\
(0.090)\end{array}$ & $\begin{array}{c}0.509 * * \\
(0.138)\end{array}$ & $\begin{array}{c}0.903^{* *} \\
(0.176)\end{array}$ & $\begin{array}{c}0.468^{* *} \\
(0.112)\end{array}$ \\
\hline $\begin{array}{l}\text { Total Average Weekly } \\
\text { Farninos }\end{array}$ & $\begin{array}{l}-0.052 \\
(0.037)\end{array}$ & -0.043 & $-0.122 * *$ & $-0.179 * *$ & $\begin{array}{l}-0.036 \\
(0.033)\end{array}$ \\
\hline Unemployment Rate & $\begin{array}{l}-0.002 \\
(0.003)\end{array}$ & $\begin{array}{l}-0.003 \\
(0.004)\end{array}$ & $\begin{array}{l}-0.006 \\
(0.008)\end{array}$ & $\begin{array}{l}-0.005 \\
(0.008)\end{array}$ & $\begin{array}{l}-0.000 \\
(0.005)\end{array}$ \\
\hline Enrollment Rate & $\begin{array}{l}-0.052 \\
(0.032)\end{array}$ & $\begin{array}{l}-0.057 \\
(0.056)\end{array}$ & $\begin{array}{c}0.050 \\
(0.067)\end{array}$ & $\begin{array}{c}-0.219 * * \\
(0.064) \\
\end{array}$ & $\begin{array}{l}-0.032 \\
(0.038)\end{array}$ \\
\hline Dep. Variable & \multicolumn{5}{|c|}{ (b) Earnings } \\
\hline Minimum Wage & $\begin{array}{c}0.021 \\
(0.046)\end{array}$ & $\begin{array}{l}-0.006 \\
(0.052)\end{array}$ & $\begin{array}{l}0.300^{* *} \\
(0.059)\end{array}$ & $\begin{array}{l}0.266^{* *} \\
(0.049)\end{array}$ & $\begin{array}{l}0.100^{* *} \\
(0.042)\end{array}$ \\
\hline Population & $\begin{array}{c}0.118 \\
(0.144)\end{array}$ & $\begin{array}{c}0.085 \\
(0.224)\end{array}$ & $\begin{array}{c}0.794 * * \\
(0.166)\end{array}$ & $\begin{array}{c}0.123 \\
(0.311)\end{array}$ & $\begin{array}{c}0.420 \\
(0.261)\end{array}$ \\
\hline Total Employment & $\begin{array}{l}-0.021 \\
(0.039)\end{array}$ & $\begin{array}{l}-0.043 \\
(0.067)\end{array}$ & $\begin{array}{l}0.161^{* *} \\
(0.055)\end{array}$ & $\begin{array}{l}-0.008 \\
(0.056)\end{array}$ & $\begin{array}{c}0.030 \\
(0.066)\end{array}$ \\
\hline Total Average Weekly & $0.098 * *$ & $0.069 * *$ & 0.101 & $0.161^{* *}$ & 0.049 \\
\hline Earnings & $(0.019)$ & $(0.027)$ & $(0.075)$ & $(0.066)$ & $(0.039)$ \\
\hline Unemployment Rate & $\begin{array}{c}0.005^{* *} \\
(0.001)\end{array}$ & $\begin{array}{l}0.007 * * \\
(0.002)\end{array}$ & $\begin{array}{l}-0.003 \\
(0.003)\end{array}$ & $\begin{array}{l}-0.003 \\
(0.002)\end{array}$ & $\begin{array}{c}0.006 * * \\
(0.002)\end{array}$ \\
\hline Enrollment Rate & $\begin{array}{l}-0.020 \\
(0.018)\end{array}$ & $\begin{array}{l}-0.020 \\
(0.024)\end{array}$ & $\begin{array}{c}-0.054^{* *} \\
(0.028)\end{array}$ & $\begin{array}{l}0.080 * * \\
(0.049)\end{array}$ & $\begin{array}{l}-0.010 \\
(0.045)\end{array}$ \\
\hline
\end{tabular}




\begin{tabular}{|c|c|c|c|c|c|c|}
\hline \multirow{3}{*}{$\begin{array}{l}\text { Table } 5 \\
\text { Industry }\end{array}$} & \multicolumn{6}{|c|}{ Estimates with County-Level Trends for the Food and Beverage Store Sector, by Right-To-Work Status } \\
\hline & \multicolumn{3}{|c|}{ Right-to-Work States } & \multicolumn{3}{|c|}{ Non-Right-to-Work States } \\
\hline & $\begin{array}{c}\text { Food and } \\
\text { Beverage Stores }\end{array}$ & $\begin{array}{c}\text { Supermarkets and } \\
\text { Other Grocery } \\
\text { Stores }\end{array}$ & $\begin{array}{l}\text { Convenience } \\
\text { Stores }\end{array}$ & $\begin{array}{c}\text { Food and } \\
\text { Beverage } \\
\text { Stores } \\
\end{array}$ & $\begin{array}{l}\text { Supermarkets } \\
\text { and Other } \\
\text { Grocery Stores }\end{array}$ & $\begin{array}{c}\text { Convenience } \\
\text { Stores }\end{array}$ \\
\hline NAICS Code & 445 & 44511 & 44512 & 445 & 44511 & 44512 \\
\hline Dep. Variable & \multicolumn{3}{|c|}{ (a) Employment } & \multicolumn{3}{|c|}{ (b) Employment } \\
\hline Minimum Wage & $\begin{array}{l}-0.186^{*} \\
(0.111)\end{array}$ & $\begin{array}{c}-0.391 * * \\
(0.124)\end{array}$ & $\begin{array}{c}0.292 \\
(0.249)\end{array}$ & $\begin{array}{c}0.167 \\
(0.120)\end{array}$ & $\begin{array}{c}0.171 \\
(0.150)\end{array}$ & $\begin{array}{l}0.244^{*} \\
(0.145)\end{array}$ \\
\hline Population & $\begin{array}{l}-0.089 \\
(0.207)\end{array}$ & $\begin{array}{l}-0.138 \\
(0.396)\end{array}$ & $\begin{array}{l}1.168 \\
(0.855)\end{array}$ & $\begin{array}{c}0.626 * * \\
(0.170)\end{array}$ & $\begin{array}{l}0.835^{* *} \\
(0.293)\end{array}$ & $\begin{array}{c}0.664 \\
(0.866)\end{array}$ \\
\hline Total Employment & $\begin{array}{c}0.338^{* *} \\
(0.059)\end{array}$ & $\begin{array}{l}0.349 * * \\
(0.165)\end{array}$ & $\begin{array}{l}0.360^{*} \\
(0.202)\end{array}$ & $\begin{array}{c}0.506^{* *} \\
(0.054)\end{array}$ & $\begin{array}{l}0.519 * * \\
(0.098)\end{array}$ & $\begin{array}{l}0.586 * * \\
(0.162)\end{array}$ \\
\hline Total Average & -0.074 & -0.099 & 0.038 & -0.036 & -0.023 & $-0.163^{* *}$ \\
\hline Weekly Earnings & $(0.036)$ & $(0.083)$ & $(0.111)$ & $(0.041)$ & $(0.062)$ & $(0.062)$ \\
\hline Unemployment & $-0.003^{*}$ & -0.005 & -0.009 & -0.003 & -0.005 & -0.005 \\
\hline Rate & $(0.002)$ & $(0.003)$ & $(0.015)$ & $(0.004)$ & $(0.006)$ & $(0.009)$ \\
\hline Enrollment Rate & $\begin{array}{c}0.028 \\
(0.049)\end{array}$ & $\begin{array}{c}0.069 \\
(0.085)\end{array}$ & $\begin{array}{c}0.130 \\
(0.217)\end{array}$ & $\begin{array}{l}-0.078 \\
(0.052)\end{array}$ & $\begin{array}{l}-0.110 \\
(0.107)\end{array}$ & $\begin{array}{c}0.066 \\
(0.092)\end{array}$ \\
\hline Dep. Variable & \multicolumn{3}{|c|}{ (c) Earnings } & \multicolumn{3}{|c|}{ (d) Earnings } \\
\hline Minimum Wage & $\begin{array}{l}0.387 * * \\
(0.079)\end{array}$ & $\begin{array}{l}0.523^{* *} \\
(0.053)\end{array}$ & $\begin{array}{l}0.238^{*} \\
(0.140)\end{array}$ & $\begin{array}{c}0.050 \\
(0.033)\end{array}$ & $\begin{array}{c}0.017 \\
(0.043)\end{array}$ & $\begin{array}{l}0.257^{* *} \\
(0.043)\end{array}$ \\
\hline Population & $\begin{array}{c}0.335^{* *} \\
(0.104)\end{array}$ & $\begin{array}{c}0.638 * * \\
(0.169)\end{array}$ & $\begin{array}{c}0.759 * * \\
(0.296)\end{array}$ & $\begin{array}{l}-0.045 \\
(0.166)\end{array}$ & $\begin{array}{l}-0.287 \\
(0.201)\end{array}$ & $\begin{array}{c}0.837^{* *} \\
(0.209)\end{array}$ \\
\hline Total Employment & $\begin{array}{c}0.027 \\
(0.041)\end{array}$ & $\begin{array}{c}0.042 \\
(0.077)\end{array}$ & $\begin{array}{c}0.106 \\
(0.106)\end{array}$ & $\begin{array}{l}-0.026 \\
(0.050)\end{array}$ & $\begin{array}{l}-0.044 \\
(0.075)\end{array}$ & $\begin{array}{c}0.130 * * \\
(0.049)\end{array}$ \\
\hline Total Average & $0.118^{* *}$ & 0.091 & $0.166^{* *}$ & $0.093^{* *}$ & $0.067 * *$ & 0.090 \\
\hline Weekly Earnings & $(0.030)$ & $(0.079)$ & $(0.074)$ & $(0.020)$ & $(0.022)$ & $(0.084)$ \\
\hline Unemployment & $0.004 * *$ & $0.004^{*}$ & 0.001 & $0.005^{* *}$ & $0.007^{* *}$ & -0.005 \\
\hline Rate & $(0.001)$ & $(0.003)$ & $(0.005)$ & $(0.002)$ & $(0.003)$ & $(0.003)$ \\
\hline Enrollment Rate & $\begin{array}{c}-0.088 * * \\
(0.034)\end{array}$ & $\begin{array}{l}-0.066 \\
(0.058)\end{array}$ & $\begin{array}{l}-0.090 \\
(0.077)\end{array}$ & $\begin{array}{c}0.001 \\
(0.023)\end{array}$ & $\begin{array}{l}-0.009 \\
(0.029)\end{array}$ & $\begin{array}{l}-0.020 \\
(0.035)\end{array}$ \\
\hline
\end{tabular}




\begin{tabular}{|c|c|c|c|c|c|}
\hline Table 6 & \multicolumn{5}{|c|}{ Regression Estimates for the Food and Beverage Store Sector: Border County Analysis } \\
\hline Industry & $\begin{array}{c}\text { Food and Beverage } \\
\text { Stores }\end{array}$ & $\begin{array}{c}\text { Supermarkets and } \\
\text { Other Grocery Stores }\end{array}$ & Convenience Stores & $\begin{array}{c}\text { Specialty Food } \\
\text { Stores }\end{array}$ & $\begin{array}{c}\text { Beer, Wine, and } \\
\text { Liquor Stores }\end{array}$ \\
\hline NAICS Code & 445 & 44511 & 44512 & 4452 & 4453 \\
\hline Dep. Variable & \multicolumn{5}{|c|}{ (a) Employment } \\
\hline Minimum Wage & $\begin{array}{l}0.262 * * \\
(0.129)\end{array}$ & $\begin{array}{c}0.023 \\
(0.182)\end{array}$ & $\begin{array}{l}0.484^{*} \\
(0.290)\end{array}$ & $\begin{array}{l}-0.013 \\
(0.341)\end{array}$ & $\begin{array}{l}0.466^{*} \\
(0.277)\end{array}$ \\
\hline Population & $\begin{array}{c}0.497 * * \\
(0.027)\end{array}$ & $\begin{array}{c}0.656^{* *} \\
(0.072)\end{array}$ & $\begin{array}{l}0.381^{*} \\
(0.227)\end{array}$ & $\begin{array}{c}0.461^{* *} \\
(0.126)\end{array}$ & $\begin{array}{l}-0.057 \\
(0.227)\end{array}$ \\
\hline Total Employment & $\begin{array}{c}0.482 * * \\
(0.024)\end{array}$ & $\begin{array}{l}0.312 * * \\
(0.047)\end{array}$ & $\begin{array}{l}0.254^{*} \\
(0.153)\end{array}$ & $\begin{array}{c}0.631 * * \\
(0.094)\end{array}$ & $\begin{array}{l}0.563 * * \\
(0.128)\end{array}$ \\
\hline Total Average Weekly & $-0.320 * *$ & -0.005 & -0.377 & $-0.708^{* *}$ & $0.729 * *$ \\
\hline Earnings & $(0.054)$ & $(0.046)$ & $(0.242)$ & $(0.176)$ & $(0.361)$ \\
\hline Unemployment Rate & $\begin{array}{c}0.004 \\
(0.004)\end{array}$ & $\begin{array}{l}-0.021^{* *} \\
(0.007)\end{array}$ & $\begin{array}{l}-0.011 \\
(0.020)\end{array}$ & $\begin{array}{l}0.033 * * \\
(0.015)\end{array}$ & $\begin{array}{c}0.008 \\
(0.019)\end{array}$ \\
\hline Enrollment Rate & $\begin{array}{c}0.295^{* *} \\
(0.077) \\
\end{array}$ & $\begin{array}{c}0.027 \\
(0.081) \\
\end{array}$ & $\begin{array}{c}0.471 \\
(0.301) \\
\end{array}$ & $\begin{array}{l}-0.176 \\
(0.116) \\
\end{array}$ & $\begin{array}{r}0.387 \\
(0.316) \\
\end{array}$ \\
\hline Dep. Variable & \multicolumn{5}{|c|}{ (b) Earnings } \\
\hline Minimum Wage & $\begin{array}{l}0.080^{*} \\
(0.046)\end{array}$ & $\begin{array}{c}0.087 \\
(0.081)\end{array}$ & $\begin{array}{l}0.319^{* *} \\
(0.071)\end{array}$ & $\begin{array}{c}0.240 \\
(0.174)\end{array}$ & $\begin{array}{c}0.107 \\
(0.098)\end{array}$ \\
\hline Population & $\begin{array}{c}0.003 \\
(0.015)\end{array}$ & $\begin{array}{c}0.025 \\
(0.039)\end{array}$ & $\begin{array}{c}-0.096 * * \\
(0.026)\end{array}$ & $\begin{array}{c}-0.163 * \\
(0.089)\end{array}$ & $\begin{array}{l}0.164 * \\
(0.085)\end{array}$ \\
\hline Total Employment & $\begin{array}{l}0.066 * * \\
(0.011)\end{array}$ & $\begin{array}{c}0.001 \\
(0.029)\end{array}$ & $\begin{array}{c}0.082 * * \\
(0.021)\end{array}$ & $\begin{array}{c}0.299 * * \\
(0.078)\end{array}$ & $\begin{array}{c}0.057 \\
(0.076)\end{array}$ \\
\hline Total Average Weekly & 0.047 & $0.163^{* *}$ & $0.157 * *$ & -0.193 & 0.050 \\
\hline Earnings & $(0.024)$ & $(0.043)$ & $(0.062)$ & $(0.140)$ & $(0.115)$ \\
\hline Unemployment Rate & $\begin{array}{l}0.003^{*} \\
(0.002)\end{array}$ & $\begin{array}{l}0.006^{*} \\
(0.003)\end{array}$ & $\begin{array}{c}0.006 \\
(0.005)\end{array}$ & $\begin{array}{l}0.015^{*} \\
(0.008)\end{array}$ & $\begin{array}{l}-0.009 \\
(0.008)\end{array}$ \\
\hline Enrollment Rate & $\begin{array}{l}-0.029 \\
(0.033)\end{array}$ & $\begin{array}{l}-0.017 \\
(0.047)\end{array}$ & $\begin{array}{l}-0.017 \\
(0.084)\end{array}$ & $\begin{array}{c}0.053 \\
(0.095)\end{array}$ & $\begin{array}{l}-0.171 \\
(0.105)\end{array}$ \\
\hline
\end{tabular}




\begin{tabular}{|c|c|c|c|c|c|}
\hline \multirow{2}{*}{$\begin{array}{l}\text { Table } 7 \\
\text { Industry }\end{array}$} & \multicolumn{5}{|c|}{ Regression Estimates with County-Level Trends for Other Retail Sectors with Low Hourly Wages } \\
\hline & Gasoline Stations & $\begin{array}{c}\text { Sporting Goods, } \\
\text { Hobby, Book, and } \\
\text { Music Stores }\end{array}$ & $\begin{array}{c}\text { General } \\
\text { Merchandise Stores }\end{array}$ & Department Stores & $\begin{array}{l}\text { Miscellaneous } \\
\text { Store Retailers }\end{array}$ \\
\hline Dep. Variable & \multicolumn{5}{|c|}{ (a) Employment } \\
\hline Minimum Wage & $\begin{array}{c}0.073 \\
(0.045)\end{array}$ & $\begin{array}{c}0.148^{* *} \\
(0.071)\end{array}$ & $\begin{array}{c}0.094^{* *} \\
(0.036)\end{array}$ & $\begin{array}{c}0.261^{* *} \\
(0.059)\end{array}$ & $\begin{array}{c}0.089 \\
(0.057)\end{array}$ \\
\hline Total Employment & $\begin{array}{c}0.365^{* *} \\
(0.034)\end{array}$ & $\begin{array}{c}0.677^{* *} \\
(0.115)\end{array}$ & $\begin{array}{c}0.536^{* *} \\
(0.061)\end{array}$ & $\begin{array}{c}0.499 * * \\
(0.108)\end{array}$ & $\begin{array}{c}0.546^{* *} \\
(0.067)\end{array}$ \\
\hline $\begin{array}{l}\text { Total Average Weekly } \\
\text { Farnings }\end{array}$ & $-0.064 * *$ & $-0.108 * *$ & $-0.149 * *$ & $-0.155^{* *}$ & -0.009 \\
\hline Unemployment Rate & $\begin{array}{c}0.001 \\
(0.002)\end{array}$ & $\begin{array}{c}0.002 \\
(0.003)\end{array}$ & $\begin{array}{l}-0.002 \\
(0.005)\end{array}$ & $\begin{array}{c}0.003 \\
(0.006)\end{array}$ & $\begin{array}{l}(0.0<0) \\
-0.006 \\
(0.003)\end{array}$ \\
\hline Population & $\begin{array}{c}0.536 * * \\
(0.168)\end{array}$ & $\begin{array}{c}0.422 * * \\
(0.130)\end{array}$ & $\begin{array}{c}0.273^{*} \\
(0.160)\end{array}$ & $\begin{array}{c}0.063 \\
(0.203)\end{array}$ & $\begin{array}{c}0.301^{* *} \\
(0.127)\end{array}$ \\
\hline Total Employment & $\begin{array}{c}0.127 * * \\
(0.035)\end{array}$ & $\begin{array}{c}0.089 * * \\
(0.037)\end{array}$ & $\begin{array}{l}-0.003 \\
(0.038)\end{array}$ & $\begin{array}{c}0.002 \\
(0.053)\end{array}$ & $\begin{array}{c}0.160^{* *} \\
(0.040)\end{array}$ \\
\hline Total Average Weekly & $0.107 * *$ & $0.076 * *$ & -0.004 & 0.001 & $0.158 * *$ \\
\hline Earnings & $(0.036)$ & $(0.025)$ & $(0.026)$ & $(0.044)$ & $(0.036)$ \\
\hline Unemployment Rate & $\begin{array}{c}0.001 \\
(0.001)\end{array}$ & $\begin{array}{l}-0.003 \\
(0.003)\end{array}$ & $\begin{array}{l}-0.001 \\
(0.002)\end{array}$ & $\begin{array}{l}-0.003 \\
(0.003)\end{array}$ & $\begin{array}{c}-0.003^{*} \\
(0.002)\end{array}$ \\
\hline Enrollment Rate & $\begin{array}{l}-0.017 \\
(0.023)\end{array}$ & $\begin{array}{c}-0.048^{* *} \\
(0.023)\end{array}$ & $\begin{array}{c}0.031 \\
(0.033)\end{array}$ & $\begin{array}{c}0.010 \\
(0.036)\end{array}$ & $\begin{array}{l}-0.001 \\
(0.018)\end{array}$ \\
\hline
\end{tabular}

